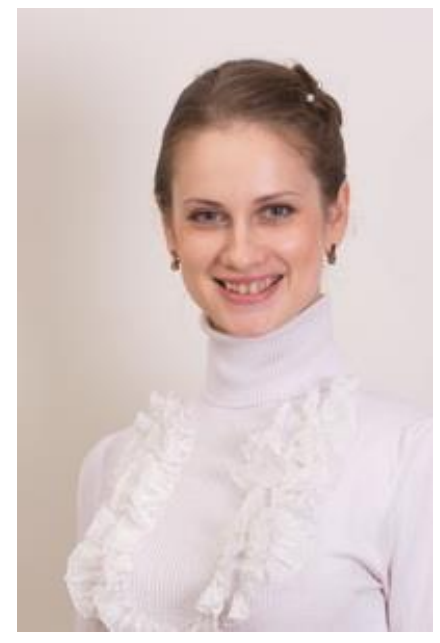

\title{
ОСОБЛИВОСТІ СОЦІАЛЬНОЇ АКТИВНОСТІ МОЛОДІ В ІНСТИТУТАХ ГРОМАДЯНСЬКОГО СУСПІЛЬСТВА
}

\author{
Оксана Ступак \\ кандидат педагогічних наук, доцент кафедри \\ менеджменту \\ Державний вищий навчальний заклад «Донбаський \\ державний педагогічний університет» \\ місто Слов'янськ, Україна \\ ORCID ID 0000-0001-6732-4569 \\ stupak.oksana.ua@gmail.com
}

Анотація. У статті представлений теоретичний аналіз та виокремлено концептуальні підходи до поняття «соціальна активність» із позицій: особистісної змістовності, способу діяльності, орієнтації на середовище. Виділено власне розуміння соціальної активності як інтегрованої особистісної діяльності людини щодо ініціювання та реалізації суспільнокорисної функції в соціальному середовищі з урахуванням вимог суспільства та особистісних ціннісних орієнтацій. Охарактеризовано поняття: «діяльність», «соціальне середовище», а також «соціальність» загалом. Виділено сфери актуалізації соціальної активності молоді в інститутах громадянського суспільства: проектна діяльність, громадсько-політична діяльність, волонтерська та благодійна діяльність, освітньо-наукова діяльність, молодіжна політика. Представлено характеристику кожної сфери із зазначенням форм, методів і роботи 3 молоддю.

Ключові слова: діяльність; молодь; соціальна активність; соціальність; соціальне середовище.

Постановка проблеми в загальному вигляді. На сьогодні активний розвиток громадянського суспільства в Україні вимагає активного залучення всіх верств населення до процесів реформування, державотворення, децентралізації на рівні громад, міст, регіонів. Тенденція останніх 5 років свідчить по активне залучення молоді до громадського сектору, проте статистичні дані соціологічних опитувань, зроблені державними установами свідчить про фрагментальну участь молоді в процесі діяльності громадських організацій, молодіжних центрів, відсутність систематичної участі. Тому виникає потреба дослідження процесів формування соціальної активності молоді в інститутах громадянського суспільства (ІГС), виділення в них сфер актуалізації соціальної активності молоді.

Аналіз останніх досліджень і публікацій. Теоретичний аналіз наукового доробку вивчення поняття «соціальна активність» дав можливість виокремити певні концептуальні підходи: 
- із позиції особистісної змістовності соціальну активність розглядають як динамічну характеристику особистості, що реалізується в системі ціннісних орієнтацій людини з урахування виконання певних соціальних ролей в суспільстві (Л. Кобышева, С. Іваненков та інші);

- із позиції способу діяльності соціальну активність характеризують як цілеспрямовану дію людини на здійснення соціальних змін (О. Безпалько, К. Ямкова та інші);

- із позиції орієнтації на середовище соціальна активність виступає як зв'язок особистості з навколишнім оточенням, який визначає напрямок і зміст, обумовлює результативність (М. Клімкіна, О. Шалабаєва І. Звєрєва, С. Харченко та інші).

Формулювання цілей статті (постановка завдання). Проаналізувати наукові підходи та виявити особливості соціальної активності молоді через обгрунтування іï сфер актуалізації в інститутах громадянського суспільства.

Результати дослідження. Беручи за базове визначення соціальної активності молоді як інтегрованої особистісної діяльності людини щодо ініціювання та реалізації суспільно корисної функції в соціальному середовищі 3 урахуванням вимог суспільства та особистісних ціннісних орієнтацій, дослідимо особливості соціальної активності молоді в інститутах громадянського суспільства. Розглядаючи змістовність цієї дефініції в контексті діяльності ІГС, доцільним вбачається охарактеризувати поняття: «діяльність», «суспільно корисні функції», «соціальне середовище», а також «соціальність» загалом.

Із позиції соціальної філософії поняття «соціальність» виступає як внутрішньо необхідне та нездоланне прагнення, що змушує людей вступати у відносини з іншими людьми для задоволення своїх потреб. Соціальність є не що інше, як практика взаємозв'язку, взаємодопомоги та солідарної діяльності людей (Таран, Зотов, Рєзанова, 2009). Поняття «соціальність» характеризують учені як системну якість, покладену в основу функціонування й розвитку суспільства будь-якого типу, водночас вона відображає спільність життєдіяльності людей. Однак соціальність не є онтологічною характеристикою спільних дій індивідів, а узагальнює відображення спільної діяльності людей, які втілені у взаємозумовленості осіб і соціальних груп матеріальними й духовними результатами діяльності інших людей, груп (Харченко, 2012).

Водночас А. Рижанова визначає такі рівні соціальності як соціальна грамотність, соціальна компетентність, соціальна культура. До однієї зі складових соціальності науковець відносить соціальну суб'єктність, що формується в процесі соціально-педагогічної діяльності. Важливо відзначити, 
що складовими соціальної суб'єктності є відчуття власної гідності, опанована свобода волі, соціальна активність, відповідальності та мужність, соціальна свідомість, усвідомлення власної соціальності, соціальне передбачення, вміння захисту від несприятливих впливів соціуму (Рижанова, 2015). Отже, якісне формування соціальної активності на основі ефективної соціально-педагогічної діяльності сприяє становленню соціальності як загальної ознаки розвиненого демократичного суспільства.

Найбільш усталені сучасні наукові погляди на сутність досліджуваного поняття особливостей соціальної активності можна знайти в довідкових та енциклопедичних джерелах. Зокрема, у Тлумачному словнику з соціальної педагогіки та соціальної роботи Л. Лохвицької поняття «діяльність» (activity) розглядається як активність суб'єкта, спрямована на взаємодію з навколишнім середовищем 3 метою задоволення власних потреб, а також спосіб існування, перетворення соціальної дійсності людиною. Проте в контексті дослідження соціальної активності нам більш цікавим є визначення «соціальної діяльності» (social activity), що розуміється як сукупність соціально значущих дій, здійснюваних суб'єктом (клас, група, особистість) у різних сферах і на різних рівнях соціальної організації суспільства, що мають на меті визначені соціальні цілі й інтереси, а також ті цілі, що використовують в ім'я досягнення i задоволення інтересів різні засоби - економічні, соціальні, політичні та ідеологічні (Лохвицька, 2017). Наголосимо, що ознаки інтегративності соціальної діяльності молодих людей вбачаються важливою характеристикою, що безпосередньо впливають на процес формування соціальної активності, бо відображають здатність молоді пристосовуватися, зокрема до різних соціальних груп, соціального середовища та соціально-економічних держаних змін узагалі.

Виходячи з проблематики дослідження, доречним убачається наголосити, що однією з провідних категорій соціальної педагогіки є соиіальне середовище як сукупність соціальних умов життєдіяльності людини (сфери суспільного життя, соціальні інституції, соціальні групи), що впливають на їі свідомість і поведінку. Із довідникових джерел відомо, що виділяють мікро- та макрорівень такого середовища. До макрорівня належить матеріальне, культурне, політичне середовище. Мікрорівень - це умови безпосереднього оточення людини (сім'я, сусідство, вулиця, навчальний та трудовий колектив, громадські організації, формальні та неформальні об'єднання тощо) (Шалабаєва, 2011).

У теорії соціалізуючого середовища С. Іваненков виокремлював три найвагоміші фактори соціалізації: речовинно-предметний, соціальноінституціональний та інформаційний (засоби масової інформації) (Іваненков, 


\section{О. СТУПАК}

Особливості соціальної активності молоді в інститутах громадянського суспільства

2003). На думку О. Безпалько, другий фактор є одним із найбільш значимих саме в територіальній громаді як особливому соціалізуючому просторі, бо тут поряд iз традиційними соціальними інститутами (сім'єю, школою, медичними та правовими установами) в умовах сьогодення важливу роль відіграють нові соціальні інституції, зокрема громадські організації, соціальні служби різного типу тощо, які мають забезпечувати необхідні умови для соціалізації особистості (Безпалько, 2006). Продовжуючи думку авторки, відзначимо, що в сучасних умовах розвитку громадянського суспільства все більшого соціалізуючого впливу на макрорівні набувають такі інститути громадянського суспільства, як молодіжні громадські організації, молодіжні центри, молодіжні ради, благодійні фонди, у діяльності яких зміст соціальної активності молоді набуває рис актуальності, своєчасності, самостійності.

Слушною є думка науковців соціальної педагогіки (Безпалько, Звєрєва, Лактіонова, Харченко, 2004), щодо соціального середовища, яке існує завдяки великій кількості взаємовідносин його членів і соціальних інститутів. Чим більша i різноманітніша палітра складових соціального середовища, тим інтенсивніший його розвиток i різноманітніші умови життєдіяльності особистості.

Розуміння соиіального середовища в дослідженні Н. Клімкіної виступає як сукупність соціальних умов життєдіяльності людини (сфери суспільного життя, соціальні інститути, соціальні групи), що впливають на іiі свідомість та поведінку. Звичайно, у соціальній поведінці чи діяльності особистості яскраво проявляються соиіальні навички, під якими розуміються «певні стратегії, які використовує індивідуум, щоб ефективно вирішувати соціальні завдання». Їх умовно можна поділити на такі групи: соціальні навички навколишнього середовища (містять уміння слухати, виконувати інструкції, виконувати навчальні завдання тощо); соціальні навички взаємодії (розв'язання конфліктних ситуацій у процесі спілкування, уміння налагодити контакт із співбесідником тощо) (Клімкіна, 2009).

Звичайно, означені соціальні навички є обов'язковими при пошуках шляхів формування соціальної активності підлітків. При цьому в соціальній активності людини чітко простежується іїі громадянська спрямованість, тобто націленість на вирішення проблем суспільного, державного й громадського характеру; виявляється в постійному пізнанні соціально-політичних, економічних, культурно-освітніх досягнень держави, прагненні до співвіднесення іiі інтересів зі своїми особистими потребами (Клімкіна, 2009). 
Сучасні наукові дослідження підтверджують актуальність проблем формування соціальної активності молоді в інститутах громадянського суспільства та характеризуються різновекторністю поглядів на сутність і зміст соціальної активності. Проаналізуємо деякі 3 наукових поглядів щодо особливостей та видів соціальної активності молоді.

Слушною $є$ думка К. Ямкової (2011), що багатофункціональність соціальної активності передбачає взаємозв'язок багатьох інтегративних якостей особистості та здійснює безпосередній формувальний вплив на ії розвиток. Тоді як змістовність соціальної активності відображається у внутрішній мотивації та ціннісних якостях людини, самореалізації в нових формах і видах діяльності, швидке пристосування до нових умов.

У контексті сучасних освітніх орієнтирів науковці виокремлюють певні види соціальної активності молоді студентського віку, що забезпечують їхній розвиток та самовдосконалення: навчальна активність (пізнавальна потреба, що сприяє формуванню системи мотивів та виражається у відповідальному відношенні до навчання та отриманні професійних знань); наукова активність (формування наукового світосприйняття, глибоких теоретичних знань, професійної позиції особистості); суспільства активність (політична та громадська культура особистості, що проявляється в діяльності громадських об'єднань); творча активність (вища форма самореалізації людини, що відображає естетичне відношення до дійсності, креативний підхід до будь-якої справи) (Кобишева, 2013).

У контексті дослідження особливостей соціальної активності молоді цікавою є шкала соціальної активності М. Левицької, що структурує суб'єктну діяльність на спонтанну активність (підписання петицій, організація демонстрації чи акції протесту, участь в акції протесту, діяльність на користь місця проживання, діяльність на користь місця праці, волонтерська праця тощо) та організаційну активність (приналежність до політичних партій, до професійних асоціацій, праця в структурах самоврядування, у будинкових комітетах, у батьківських комітетах, участь у товариствах за інтересами, в парафіяльних чи при церковних організаціях та в інших організаціях) (Чолій, 2010). Додамо, що рівень соціальної активності в цьому випадку може залежати від загального рівня громадської активності та соціально-економічного розвитку певного регіону, розгалуженості структури неформальних громадських об’єднань, сфери їхньої діяльності.

Розвиваючи окреслену думку, важливо відзначити широкий спектр форм i засобів соціальної активності молоді, зокрема участь молодих людей у процесі 
вирішення проблем, що стосуються їх та місцевої громади, вбачаються найвагомішим виявом соціальної активності. Вибір форми участі обумовлений особистісними ціннісними орієнтирами, досвідом громадської діяльності чи доречністю використання в окремому випадку, проте кожна з цих форм має свій потенціал та свої обмеження.

Відзначимо, що в дослідженні серед достатньої кількості інститутів громадянського суспільства ми виділили такі, що мають найбільше значення в процесі формування соціальної активності молоді, зокрема: громадські організації, молодіжні центри, молодіжні ради, благодійні фонди. Водночас доцільним є виокремлення сфер актуалізації соціальної активності молоді в наведених інститутах: проектна діяльність (участь в молодіжних проектах; самостійна реалізація соціально-значимих проектів; фандрайзингова діяльність; участь в грантових програмах на отримання фінансування проектів); громадсько-політична діяльність (участь у виборах місцевого та державного рівнів; подання та підписання електронних петицій; участь та організація адвокаційних компаній; зустрічі 3 політичними діячами, депутатами, чиновниками); волонтерська та благодійна діяльність (соціальні акції; благодійні компанії; допомога соціально-незахищеним верствам населення; волонтерська практика); освітньо-наукова діяльність (тренінги; семінари; форуми; освітні компанії); молодіжна політика (участь молоді в процесі прийняття рішень на локальному рівні; консультації з державними органами влади; співпраця з владою у вирішення соціально важливих проблем молоді).

Проаналізуємо детальніше сфери актуалізації та характеристики форм соціальної активності молоді в інститутах громадянського суспільства.

Вирішуючи завдання нашого дослідження, ми маємо врахувати, що в діяльності інститутів громадянського суспільства на сьогодні важливе місця посідає проектна діяльність, бо зазначається великий інтерес з боку міжнародних та європейських донорів до розбудови українського суспільства. У цій діяльності й можна простежити за тими орієнтирами, до яких прагне сучасна молодь. Широкий спектр міжнародних, всеукраїнських, регіональних проєктів для молоді залучає активних людей до розвитку власного потенціалу, формування стійких життєвих цінностей тощо. Водночас важливим етапом проектної діяльності для молоді є самостійне планування, пошук ресурсів для реалізації (фандразингова діяльність) та безпосереднє втілення своєї ідеї в життя. Оскільки робота над проектами, які реалізовують молоді люди, відображають як уміння планувати, організовувати власну діяльність, працювати в колективі, вміння 
домовлятися та вести переговори, так i механізми вирішення тих гострих проблем, що на думку молоді потребують негайного втручання та розв’язання. Серед найпоширеніших грантових програм для молоді, що на конкурсній основі поданих проєктних пропозицій надають фінансову підтримку реалізації проєктів, можна виокремити такі:

- фонд ООН (ЮНІСЕФ) - підтримує Уряд України в створенні програм 3 охорони здоров'я, харчування, освіти та захисту для дітей; програму 3 відновлення та розбудови миру, демократичне врядування, сталий розвиток $\mathrm{i}$ довкілля;

- USAID (Агентство США з міжнародного розвитку) - здійснює заходи 3 міжнародного розвитку та допомоги в надзвичайних ситуаціях на основі партнерських стосунків i надання ресурсів, які рятують людські життя, знижують рівень бідності та зміцнюють механізми демократичного врядування, допомагаючи долати гуманітарні кризи та ставати на шлях самостійного розвитку;

- посольства Німеччини, Великої Британії, США, Нідерландів та інші;

- благодійні та громадські організації, фонди приватних осіб (наприклад, Фонд Богдана Колєсникова, BEARR Trust, чеська організація «Людина в біді», благодійний фонд Карітас тощо).

Названі організації проявили активну діяльність на сході Україні після 2014 року, підтримавши відновлення інфраструктури, родини, що постраждали від конфлікту, а також інститути громадянського суспільства на шляху впровадження програм підтримки молоді в розбудові громадянського суспільства, зокрема в східній частині країни.

Соціальна активність як особистісна якість особистості демонструє власний погляд на соціально-економічні процеси, державні орієнтири та політичні зміни, тому однією зі сфер іiі актуалізації є громадсько-політична діяльність молоді. Вона відображається в безпосередній громадсько-свідомій позиції щодо власної участі в процесі державотворчих перетворень, прагненні змінити на краще умови молодіжного середовища, впровадженні сталих ціннісних орієнтирів. Серед форм соціальної активності молоді в даному контексті можна виокремити: участь у виборах місцевого та державного рівнів; подання та підписання електронних петицій; участь та організація адвокаційних компаній; зустрічі з політичними діячами, депутатами, чиновниками. Звичайно даний перелік форм не відображає всі можливі прояву соціальної активності під час громадсько-політичної діяльності, але демонструє певні вектори молодіжної активності, що актуальні для інститутів громадського суспільства. 
Ще однією досить соціально важливою сферою актуалізації соціальної активності молоді в межах нашого дослідження вбачається волонтерська та благодійна діяльність як відображення соціально значимої, безкорисної ініціативи на благо певної групи людей. Волонтерська діяльність завжди привертала увагу дослідників соціальної педагогіки. Зокрема, Т. Лях, зазначає, що для України, як і для всього світу, волонтерство $є$ актуальним і важливим 3 різних причин. По-перше, як свідчить багаторічний досвід використання праці волонтерів, це ефективний спосіб вирішувати складні проблеми окремої людини, суспільства та довкілля, які часто виникають на грунті недостатньої турботи про суспільне благо. По-друге, волонтерство приносить у соціальну сферу нові, як правило, творчі та сміливі ідеї щодо вирішення найгостріших і найскладніших проблем. Тому саме завдяки йому безвихідні, на перший погляд, ситуації знаходять своє вирішення. По-третє, волонтерство - це спосіб, за допомогою якого кожний представник суспільства може брати участь у покращенні якості життя. По-четверте, це механізм, за допомогою якого люди можуть прямо адресувати свої проблеми тим, хто здатний їх вирішити (Лях, 2009). Тоді як, благодійність в енциклопедичній літературі розглядається багатоаспектна людська діяльність 3 метою надання певної допомоги окремій особі чи соціальній групі, комплексний (соціальний, психологічний та економічний) феномен, що має свої давні традиції (Павленок, 2001).

У контексті дослідження проблеми формування соціальної активності молоді в інститутах громадянського суспільства важливими вбачається такі форми діяльності, як соціальні акції, благодійні компанії, допомога соціальнонезахищеним верствам населення, волонтерська практика. На наш погляд, саме ці форми прояву активності серед молоді знаходяться серед пріоритетів громадської діяльності молодіжних організації та центрів, а також молодіжних рад, оскільки передбачають систематичне або разове проведення соціальнокорисних заходів. Так, наприклад, Ukrainian Volunteer Service - громадська організація, що розвиває волонтерство в Україні. Серед пріоритетних завдань організації $\epsilon$ об'єднання людей навколо соціальних проблем, залучення волонтерів до участі у соціальних проектах, освітніх та культурних заходах, проведення інформаційних кампаній та освітніх проектів аби довести, що волонтерство варте уваги кожного (Ukrainian Volunteer).

Освітні можливості навчальних закладів на формування соціальної активності молоді має безумовно вагомий вплив, що відображається в педагогічних та освітніх технологіях, формах організації начальних занять, широким спектром позанавчальних виховних заходів, що в більшості не 


\section{О. СТУПАК}

Особливості соціальної активності молоді в інститутах громадянського суспільства

передбачає діяльність інститутів громадянського суспільства. Проте поруч із формальними начальними процесами на сьогодні в час становлення освітньої реформи провідне місце посідають засоби неформальної та інформальної освіти. Уперше на законодавчому рівні дані поняття закріплені в Законі Україні «Про освіту», затвердженому в 2017 році. Відповідно до названого документа неформальна освіта розглядається як освіта, що здобувається, як правило, за освітніми програмами та не передбачає присудження визнаних державою освітніх кваліфікацій за рівнями освіти, але може завершуватися присвоєнням професійних та/або присудженням часткових освітніх кваліфікацій. Тоді як інформальна освіта (самоосвіта) передбачає самоорганізоване здобуття особою певних компетентностей, зокрема під час повсякденної діяльності, пов'язаної 3 професійною, громадською або іншою діяльністю, родиною чи дозвіллям (Закон про освіту, 2017). Так, широкі можливості неформальної освіти (тренінги, семінари, форуми, освітні компанії) виступають одними 3 ключових форм соціальної активності молоді під час освітньо-наукова діяльності як сфери актуалізації соціальної активності.

Названі сфери актуалізації соціальної активності молоді можуть відповідати діяльності різних громадських угрупувань, проте в контексті нашої дисертаційної роботи провідне місце посідають саме молодіжні громадські організації, молодіжні центри, молодіжні ради та благодійні організації. На нашу думку, ключовою сферою актуалізації соціальної активності молоді виступає молодіжна політика, яка не лише виступає каталізатором ініціативності для молоді, а й демонструє результативний вплив молоді на вирішення різних соціальних, громадських проблем.

Висновки. Підсумовуючи викладене вище, зазначимо, що виділені нами сфери актуалізації та форми соціальної активності молоді не вичерпують усього спектру молодіжної активності, проте конкретизують змістовну наповненість поняття «соціальна активність» у межах дослідження 3 урахуванням особливостей діяльності та можливостей інститутів громадянського суспільства та визначають вектори подальшої роботи щодо розробки структурнокомпонентного складу соціальної активності молоді та виділення системи іiі формування.

\section{СПИСОК ВИКОРИСТАНИХ ДЖЕРЕЛ}

1. Безпалько, О. (2006). Організація сочіально-педагогічної роботи з дітьли та молоддю у територіальній громаді: теоретико-методичні основи. Київ, Україна: Наук. світ.

2. Закон про освіту. Взято з https://zakon.rada.gov.ua/laws/show/2145-19. 
Особливості соціальної активності молоді в інститутах громадянського суспільства

3. Звєрєва, І., Безпалько, О. та ін. (2004). Сочіальна робота в Україні. Київ, Україна: Центр навчальної літератури.

4. Иваненков, С. (2003). Проблемы социализаџии современной молодежи. СПб, Российская Федерация: Буква.

5. Клімкіна, Н. (2009). Формування сочіальної активності підлітків із неповних сімей у навчально-виховному процесі основної школи. (Дисертація канд. пед. наук). Київ, Україна: Національний педагогічний університет імені М. П. Драгоманова.

6. Кобышева, Л. (2013). Влияние социальной активности на нравственное самоопределение студентов. Интернет-журнал «Науковедение», 4, 33-38.

7. Лохвицька, Л. (2017). Тлумачний словник-мінімум із соціальної педагогіки та соиіальної роботи. Київ, Україна: Мандрівець.

8. Лях, Т. (2009). Соціально-педагогічна діяльність студентських волонтерських груn. (Дисертація доктора пед. наук). Київ, Україна: Київський національний університет імені Тараса Шевченка).

9. Павленок, П. (2001). Краткий словарь по социологии. Москва, Российская Федерация: ИНФРА.

10. Рижанова, А. (2015). Розвиток соціальної суб’єктності та принцип субсидіарності соціально-педагогічної діяльності. Педагогіка та психологія, 5(48), 130-141.

11. Таран, В., Зотов, В., Рєзанова, Н. (2009). Соиіальна філософія. Київ, Україна: Центр учбової літератури.

12. Харченко, С. (2012). Значення категорії «соціальність»у пошуках методологічної основи розвитку сучасної соціально-педагогічної науки. Соціальна педагогіка: теорія та практика, 3, 4-13.

13. Чолій, С. (2010). Мотиваційно-ціннісний аспект соціальної активності молоді. Збірник наукових праць КПНУ імені Івана Огієнка, Інституту психології ім. Г. С. Костюка АПН України. Проблеми сучасної психологї̈, 10, 808-822.

14. Шалабаєва, О. (2011). Социальная активность старшеклассников в психологопедагогической науке. Вестник ЧГПУ. Педагогика и психология, 9, 235-241.

15. Ямкова, К. (2011). Визначення сутності та змісту соціальної активності в науковій думці. Науковий вісник Мелітопольського державного педагогічного університету. Серія педагогіка, 5, 357-365.

\title{
FEATURES OF SOCIAL ACTIVITY OF YOUTH IN CIVIL SOCIETY INSTITUTIONS
}

\author{
Oksana Stupak \\ Candidate of Pedagogical Sciences, Associate Professor, \\ Associate Professor of Department of Management, \\ SHEI "Donbas State Pedagogical University", \\ Sloviansk, Ukraine \\ ORCID ID 0000-0001-6732-4569 \\ stupak.oksana.ua@gmail.com
}

\begin{abstract}
The presented theoretical analysis of approaches to understanding social activity makes it possible to regard it as an integrated personal activity concerning initiation and implementation of socially useful function in a social environment, taking into account the requirements of society and personal value orientations. The logic of the research studies the characteristic of the concepts of "activity", "socially useful functions", "social environment", as well
\end{abstract}




\section{О. СТУПАК}

Особливості соціальної активності молоді в інститутах громадянського суспільства

as "sociality" in general. Some of the scientific views on the features and types of social activity of young people are analyzed, they are: learning activity (cognitive need that contributes to the development of a system of motives and is expressed in a responsible attitude to learning and obtaining professional knowledge); scientific activity (development of scientific outlook, deep theoretical knowledge, professional position of a person); social activity (political and public culture of a person, manifested in the activities of public associations); creative activity (the highest form of self-realization of a person, reflecting an aesthetic attitude to reality and creative approach to any activity).

Based on the fact that youth is a socially active group of people, passing an important stage of social maturity, entering adulthood, and choosing their own path of establishment, development and self-affirmation. A key platform for self-realization, self-development of youth, and, as a result, the development of practical communication skills, interaction with government institutions, volunteer activities, contains various forms of civil society institutions. In our opinion, they are considered to be public youth organizations, charitable foundations, youth centers, and youth public councils as effective forms of youth interaction.

The theoretical analysis of the problem under study made it possible to highlight certain peculiarities of young people's social activity in civil society institutes. In particular, to justify the areas of its actualization, as follows: project activity involving participation in youth projects, independent realization of socially significant projects, fundraising activity, participation in grant programs for project financing; public-political activities (participation in elections on local and state levels, submission and signing of electronic petitions, participation and organization of advocacy companies, meetings with political figures, deputies, officials); volunteer and charitable activities (social actions, charitable companies, assistance of socially vulnerable groups of the population, volunteer practice); educational and scientific activities (trainings, seminars, forums, educational companies); youth policy (participation of young people in decision-making processes at the local level, consultations with state authorities, cooperation with the authorities in solving socially important problems of youth).

Within our research, taking into account the peculiarities of the activity and opportunities of civil society institutions, the vectors of further work on the development of the structural and component composition of youth social activity and the allocation of the system for its formation are determined.

Key words: social activity, youth, sociability, social environment, activity.

\section{REFERENCES}

1. Bezpalko, O. (2006). Organization of Social and Pedagogical Work with Children and Youth in the Territorial Community: Theoretical and Methodological Foundations. Kyiv, Ukraine: Nauk. svit.

2. Law of Ukraine on Education. № 2145-19. (2017, September 5). Retrieved from http://zakon2.rada.gov.ua/laws/show/2145-19.

3. Zvierieva, I., Bezpalko, O. and others. (2004). Social Work in Ukraine. Kyiv,Ukraine: Tsentr navchalnoi literatury.

4. Ivanenkov, S. (2003). Problems of Socialization of Modern Youth. St. Petersburg, the Russian Federation: Bukva.

5. Klimkina, N. (2009). Formation of Social Activity of Single-Parent Adolescents in Primary School Educational Process. (PhD dissertation). Kyiv, Ukraine: Natsionalnyi universytet imeni M. P. Drahomanova.

6. Kobysheva, L. (2013). The Influence of Social Activity on Students' Moral SelfDetermination. Internet-zhurnal "Naukovedenie", 4, 33-38.

7. Lokhvitska, L. (2017). An Interpretive Minimum Vocabulary of Social Pedagogy and Social Work. Kyiv, Ukraine: Mandrivets.

Професіоналізм педагога: теоретичні й методичні аспекти. - Вип. 10. - Слов'янськ, 2019. 
Особливості соціальної активності молоді в інститутах громадянського суспільства

8. Liakh, T. (2009). Socio-pedagogical Activities of Student Volunteer Groups. (Doctoral dissertation). Kyiv, Ukraine: Kyivskyi Natsionalnyi Universytet imeni Tarasa Shevchenka.

9. Pavlenok, P. (2001). A Concise Sociology Dictionary. Moscow, the Russian Federation: INFRA.

10. Ryzhanova, A. (2015). Development of Social Subjectivity and the Principle of Subsidiarity of Social and Pedagogical Activity. Pedahohika ta psykholohiia, 5(48), 130-141.

11. Taran, V., Zotov, V., \& Riezanova, N. (2009). Social Philosophy. Kyiv, UkraineTsentr uchbovoi literatury.

12. Kharchenko, S. (2012). The Importance of the Category "Sociality" in Search of a Methodological Basis for the Development of Modern Socio-Pedagogical Science. Sotsialna Pedahohika: teoriia i praktyka, 3, 4-13.

13. Cholii, S. (2010). Motivational and Value Aspect of Youth Social Activity. Zbirnyk naukovykh prats KPNU imeni Ivana Ohiienka, Instytut psykholohii im. H. S. Kostiuka APN Ukrainy, $10,808-822$.

14. Shalabaieva, O. (2011). Social Activity of High School Students in Psychological and Pedagogical Science. Vestnik ChGPU. Pedagogika i psihologiya, 9, 235-241.

15. Yamkova, K. (2011). Determination of the Essence and Content of Social Activity in Scientific Thought. Naukovyi visnyk Melitopolskoho derzhavnoho pedahohichnoho universytetu. Seriia pedahohika, 5, 357-365.

Матеріали надійшли до редакції 30.08.2019 p. 